\title{
Family Law Book as Fourth BoOK OF the new Hungarian Civil Code ${ }^{1}$
}

\author{
Orsolya Szeibert ${ }^{2}$ \\ Faculty of Law, Eötvös Loránd University, Budapest, Hungary \\ email: szeibert@ajk.elte.hu
}

SZEIBERT, Orsolya. Family Law Book as Fourth Book of the new Hungarian Civil Code. International and Comparative Law Review, 2013, Vol. 13., No. 2, pp. 85-95. DOI: 10.1515/iclr-2016-0072.

\begin{abstract}
Hungarian family law is regulated primarily in the Family Act today. This Act was accepted in 1952 but as it has been modified several times it serves the legal interests of family and family members in harmony with European standards. Nevertheless, the idea of codifying a new Civil Code in 1998 raised the question whether family law should have been included in a new Civil Code. The scientific opinions were diverging on this issue at that time, but later on it became accepted that family law should get back into the corpus of a Civil Code. The article gives an analysis of the developments and most recent changes.
\end{abstract}

Keywords: conscientious objection, freedom of conscience and religion, European Convention on Human Rights

\section{The codification of the new Hungarian Civil Code and trends in the Family Law Book}

The recodification of the new Hungarian Civil Code began in 1998. After several stages and curves the codification resulted in a Bill which was submitted to the Parliament in July 2012. The Parliament discussed it in autumn and winter 2012. This Act on new Civil Code was accepted on 11 February 2013 and enters into force on 15 March 2014. The Hungarian Civil Code that is Act No. V 2013 is consisted of Books among which family law creates the fourth one (Fourth Book: Family Law). The basic concept of family law was the maintenance of the well-based and well-working detailed rules and the modification of the existing rules in well-reasoned cases.

The new family law rules tend to keep step with the new challenges and tendencies while maintaining the traditional institutions of family law. The challenges with which family law is facing in Hungary are the decreasing number of marriages, the increasing number of divorces, the growing number of cohabit-

1 This paper was supported by the Hungarian Scientific Research Fund (OTKA PD 83548).

2 Orsolya Szeibert Dr. PhD associate professor Department of Civil Law, Faculty of Law, Eötvös Loránd University, Budapest.

3 Act No. V 2013 was promulgated in the Hungarian Official Gazette (Magyar Közlöny) No 31 of 2013 on 26 February 2013. 
ants, the legal demands of the same-sex partners, the complexity of spouses' and cohabitants' property relations, the growing need of taking into attention the child's rights and interests specially in a case when his or her family is breaking up.

In the following the family law principles, the marriage including its personal and property law consequences, the non-marital partnerships, that is registered partnership and cohabitation, and lastly the parental responsibility and the child-parent contact are to be introduced.

\section{Main Parts of the Family Law Book and the family law principles}

The Family Law Book is consisted of five Parts, these are the following: principles, marriage, family law consequences of cohabitation, relationship of relatives and guardianship. While the principles and cohabitation's family law consequences do not take up too much room in the Family Law Book the marital relationship and its legal consequences are regulated deeply such as the relationship of relatives in the frames of which the child-parent relationship is covered by complex rules.

Four principles introduce the Family Law Book with the aim of emphasizing that family law is a special branch of civil law where distinguished legal rules are to be applied upon special considerations. The principles are the following: protection of marriage and family, protection of the child's interest, equality of spouses and lastly fairness and the protection of the weaker party. ${ }^{4}$ All principles affect the child's position and his or her interests.

The protection of family and marriage - as the first principle - reminds not only the notion in the Family Act but reflects the wording of the Basic $\mathrm{Law}^{5}$ of Hungary. Although the Family Act being in force now guarantees the protection of the child's rights and interests, the new Civil Code emphasizes some children's rights. According to the second principle the child's interests and rights are specially protected in family relationships and the child has the right to be brought up in his or her own family. If it is not possible it has to be guaranteed that the child should be brought up in familial environment as far as possible and maintain his or her family relationships. According to the last paragraph the rights of the child to be brought up in his or her family or familial environment and maintain the family relationship should be restricted only in legally determined cases, exceptionally and only in the child's interest. Thirdly, the Family Law Book repeats a classic family law principle as the spouses are equal both in family issues and in the issues of their matrimonial life. Fairness and protection of weaker party are rather new principles even if the protection of the weaker

4 \$\$ 4:1-4:4

5 The Basic Law was accepted in April 2011 and entered into force on 1 January 2012.

(C) Palacký University Olomouc, Czech Republic, 2013. ISSN 1213-8770 (print), ISSN: 2464-6601 (online). 
party has already been applied according to the concrete circumstances in a certain case. Fairness is required in the Family Act as the court has to render the spouses' property relations with regard to the requirement of fairness which is nevertheless applied in the judiciary on an exceptional basis.

\section{Marriage}

\section{The concept and protection of marriage}

Marriage has remained the issue of the first and huge part of the Family Law Book. This kind of regulation is in harmony with the Family Act being in force now and the Basic Law according to which Hungary protects the institution of marriage, the conjugal union of a man and a woman based on voluntary and mutual consent and the family; and one basis of the family is marriage. ${ }^{6}$

Although the notion is marriage is not defined in the Family Law Book its legal consequences are far reaching as in other European family law jurisdictions. The importance of marital status is reflected in the fact that the above mentioned new principles of Family Law Book deal primarily with marriage and the legal situation of spouses. Although there are three types of marital or nonmarital partnerships in Hungary ${ }^{7}$ the Family Law Book principle contains the equality definitely only with regard to spouses.

\section{Personal legal consequences of marriage}

Marriage has the widest spectrum of personal legal consequences in comparison with other partnerships. Fidelity is required from the spouses and they should cooperate to reach common aims and support each other. ${ }^{8}$ According to the Family Law Book spouses should reach common decisions in the issues of the marital and family life while in their own personal issues they should decide on their own with regard to the common child's and the other spouse's interests. ${ }^{9}$ Hungarian law generally treat the issue of name-bearing really strictly and it is reflected in the manner of regulating the spouses' names. An emphasized right of the spouses that they may change their names after marrying and this right

6 Article L) of Basic Law. According to Article L) "Hungary shall protect the institution of marriage, the conjugal union of a man and a woman based on voluntary and mutual consent and the family as the basis for survival of the nation. The basis of the family is marriage and parent-child relationship."

7 See Orsolya Szeibert, Cohabitation, Registered Partnership and their Financial Consequences in Hungary, in Bill Atkin (ed), The International Survey of Family Law 2009 Edition (Jordan Publishing Limited, 2009) pp 203-213.; Orsolya Szeibert, Partnerships in Hungary in the light of the new legal developments: status or contract?, in Bill Atkin (ed), The International Survey of Family Law 2012 Edition (Jordan Publishing Limited, 2012) pp 115-122.

$8 § 4: 24(1)$

$9 \S 4: 25$ 
cannot be exercised by either registered partners or de facto cohabitants. Both the husband and the wife may change his or her earlier family name and according to the detailed rules they may choose and bear a common or linked family name, too. ${ }^{10}$

\section{Property relations of spouses}

The property relations of spouses are regulated expansively. The Family Law Book contains regulations concerning the property relations of spouses, the default matrimonial property regime, alternative matrimonial property regimes, usage of the common dwelling and the maintenance of the former spouse.

\subsection{Default matrimonial property regime}

According to the Family Act the default matrimonial property regime is the community of property regime. ${ }^{11}$ It was introduced as the only system in 1952. The community of property regime tends to create a balance between the spouses, their work and contribution to the common life. This default matrimonial property system is maintained in the Family Law Book. In the frames of community of property regime each spouse has its own separate property and they have a common property. The Act enumerates the categories of separate property in the form of a non-exhaustive list. The property acquired before marriage, the inherited property, the property acquired as a gift, the property which does not exceed the usual extent or quantity, the property which provides one of the spouses' personal needs and the property replacing the separate property belongs to the personal property of the spouses. The common property is not listed in the Act as each asset which is acquired by the spouses or either of them in the course of the matrimonial community of life belongs to the common property as a main rule, except for the separate property.

In matrimonial property cases brought before the court several issues may concern the legal nature of the asset. The spouses as parties to a legal case often debate the beginning of the matrimonial community of life or the financial contribution to the acquirement of an asset. In order to suit this claims the judiciary has developed some legal presumptions. If the fact is debated whether there was matrimonial community of life between the spouses in a period of time, the legal presumption is that while the matrimonial bond connected the spouses to each other the matrimonial community of life existed as well. The burden of proof is on the spouse who debates it. Sometimes the matrimonial community life begins later than the marriage itself but this problem emerges rather at the end of the common life: the spouses finish their community of life months or even years before the divorce.

$10 \$ \$ 4: 27-4: 28$

$11 \$ 4: 34(2)$

(C) Palacký University Olomouc, Czech Republic, 2013. ISSN 1213-8770 (print), ISSN: 2464-6601 (online). 
Another legal presumption is that each asset concerning which there is a debate between the spouses whether it belongs to the common property or the separate property, belongs to the common property. The proof is burdened on the party who wants to see it as his or her separate property. Another problem concerning the same issue is whether there happened any contribution from either spouse. After long years of a marriage in a community of property regime it is difficult to identify an asset as it belongs partly to the common property and partly to one spouse's separate property. Each party has to prove the contribution from the separate property unless the legal presumption according to which there happened no such contribution wins. The presumptions concerning the matrimonial life and the common property create part of the normative rules in the new Family Law Book. ${ }^{12}$

\subsection{Alternative matrimonial property regimes}

When the Family Act was enacted the community of property regime as the default property regime was the obligatory one and the spouses could not deviate. The possibility of matrimonial property agreement was reintroduced into the Hungarian family law in 1986. The current rule of the Family Act states that the spouses or future spouses may enter into a matrimonial property agreement for the time of their matrimonial community of life. Nevertheless, in the Family Act the matrimonial property agreement is regulated laconically. This will change in the Family Law Book as it promotes the matrimonial property agreement and emphasises the contractual freedom of the spouses. The spouses may deviate from the rules of the default matrimonial property regime but with the aim of providing the details the Family Law Book introduces two alternative matrimonial property regimes and gives rather detailed rules for the spouses' contracts altogether.

The so-called model rules of the regime of participation in acquisitions and those of separation of property appear in the new Civil Code. ${ }^{13}$ Although these are brand new rules both regimes were known and applied in Hungary before the 1950s. During the codification of the model rules also the experiences and difficulties of that earlier Hungarian judiciary were taken into attention. Nevertheless, the spouses may deviate also from the rules of the alternative matrimonial property regimes. The register of matrimonial property agreements is proposed to be set up with the aim of securing the interests of third parties and creditors.

$12 \S 4.35(1), \S 4: 37, \S 4: 40$. See the Hungarian answers (Orsolya Szeibert and Emilia Weiss) on the detailed rules of Hungarian matrimonial property regime as regulated in the Family Act in: Katharina Boele-Woelki, Bente Braat and Ian Curry-Sumner (eds.), European Family Law in Action Vol. IV: Property Relations Between Spouses (Intersentia, 2009)

$13 \$ \$ 4: 63-4: 74$ 


\section{Maintenance of the former spouse}

The rules of maintenance of the former spouse ${ }^{14}$ are kept in the Family Law Book and the conditions for maintenance have not been changed. These requirements are the lack of means and the lack of unworthiness on the claimant's side and the ability of the debtor to pay. Unworthiness depends on the behaviour of the claimant during the marital life. According to the Hungarian judicature the behaviour which broke the moral basis of marriage and contributed to the irretrievable and total breakdown of married life is to be taken into attention. Even if all conditions are fulfilled, the court cannot order spousal maintenance if the debtor is unable to pay. The court takes into consideration the debtor's ability to work, his or her real earning capacity and his or her assets. Whether the debtor is expected to use his or her assets in order to fulfil his or her maintenance obligation depends on the kind of assets. The amount of maintenance, which is generally to be paid in periodical payments, depends on several circumstances, namely the level of lacking of means, the ability of the debtor to pay, the standards of living of both spouses. Those are taken into consideration when the court determines the exact amount of maintenance.

Although the regulation concerning spousal maintenance preserves the rules of the Family Act, some brave new rules are appearing. The Family Law Book evaluates the extremely short marriage and the lack of common child. If the marital life lasted not as long as one year and the spouses did not have a common child the maximum duration of spousal maintenance after divorce may not exceed the duration of the marital life as a main rule. ${ }^{15}$ The competent court may not order the maintenance in lump sum but the spouses may enter into an agreement according to which the obligation should be performed in a lump sum payment. ${ }^{16}$ That shows the acceptance of the principle of "clean break" at least in case of agreement. A third point is that the claim for spousal maintenance may be revealed today and this possibility is not sustained at all. The right to spousal maintenance ceases not only when the claimant enters into a new marriage or establishes a registered partnership but also in case of cohabitation. ${ }^{17}$

14 See the Hungarian answers (Orsolya Szeibert and Emilia Weiss) on the detailed rules of Hungarian spousal maintenance as regulated in the Family Act in: Katharina Boele-Woelki, Bente Braat and Ian Sumner (eds.), European Family Law in Action Vol. II: Maintenance Between Former Spouses (Intersentia, 2003)

$15 \$ 4: 29(3)$

$16 \$ 4: 32$

$17 \$ 4: 33$ 


\section{Non-marital partnerships}

\section{Registered partnership}

Registered partnership is regulated in Hungary in the Act No XXIX of 2009. ${ }^{18}$ Although registered partnership creates personal status like marriage it is not even mentioned in the new Civil Code. Two same sex persons above 18 may establish a registered partnership by the same process as a marriage which means that the declaration of the parties' identical intention creates registered partnership. The principle of monogamy means in this context that not only an existing marriage but also an existing registered partnership will result in a new marriage or registered partnership being regarded as void.

Today a main rule is that in issues not regulated by the Act of 2009 the rules of the Family Act concerning marriage are to be applied analogously and as the acquired rights of registered partners cannot be modified the Act of 2009 will escort the new Civil Code in this sense.

The property consequences of registered partnership are the same in their entirety as those of marriage including inheritance rights as well. However, while the personal legal consequences are also the same as in case of marriage as a main rule, the Act of 2009 mentions the exceptions. Registered partners cannot use their partner's surname at least by the change of the personal status, they cannot adopt a child together and cannot take part in a medically assisted reproduction process. Albeit a registered partnership may be terminated by court which corresponds to divorce, an extra method of termination is also available for registered partners being not opened for spouses it is the termination by public notary.

\section{Cohabitation}

Cohabitation which is regulated today in the Civil Code of 1959 will create part of the new Civil Code in two Books. Cohabitants appear both in the Sixth Book and in the Fourth Book. According to the Hungarian legal viewpoint cohabitation is a contract which is to be regulated outside of the Family Law Book. That is why the cohabitation and some legal consequences are regulated in the Book of Obligations. However, cohabitation may procure so-called family law consequences but only if the cohabitants have common child and their relationship lasted at least one year long.

\subsection{Cohabitation as a contract between cohabitants}

Sixth Book of the new Civil Code provides rules for the definition of cohabitation, the property issues and the possibility of arranging the usage of the common dwelling after the termination of the cohabitation by contract.

18 Act No XXIX of 2009 on Registered Partnership and the Modification of Legal Rules in Connection with Registered Partnership and the Facilitation of the Proof of Cohabitation. 
The notion of cohabitation does not change as cohabitants are two persons, whether different sex or same sex, who live together, without entering into a marriage or a registered partnership, in a common household, in an emotional fellowship and in an economic partnership (community of life) and they are not related to each other in direct line ${ }^{19}$ They cannot be siblings or half-siblings and neither of them can live at the same time in a marital community of life, a community of life in a registered partnership or in cohabitation with a third person.

What regards their property relations the default property regime resembles the regime of acquisitions of property which is an alternative property regime for spouses. Just as in case of marriage, also in case of cohabitants the cohabitants' property agreement is highly promoted and the cohabitants may create the contractual terms as freely as the spouses even if there are cogent rules in both cases. ${ }^{20}$

\subsection{Family law impacts of cohabitation}

If the partners live together at least one year long and they have a common child either of them may refer to the family law consequences of the relationship. These consequences are incorporated in the Family Law Book and concern the maintenance the former cohabitant and the possibility of a court decision on the usage of the common dwelling by the former cohabitant. ${ }^{21}$ Both rules of the maintenance and those of usage of the common flat derive from the marital regulations respectively. Nevertheless, there are clear distinctions in both cases with the aim of not to provide as severe ruling as for spouses.

Although it is not regulated definitely it goes without saying that on the field of parental responsibilities the cohabitants have the same rights and obligations as spouses. The establishment of the parental status does not happen the same way as in case of spouses. The paternal status does not emerge automatically and the cohabitants cannot adopt a child together. However, they can take part in medically assisted reproduction processes provided that they are different-sex persons.

\section{Parental responsibilities}

\section{Joint parental responsibilities}

If the parents live together the parental responsibilities are exercised jointly and independently of the fact whether they are spouses or cohabitants. Nevertheless, even if they live apart from each other the joint parental responsibilities

19 See Orsolya Szeibert-Erdős,Unmarried Partnerships in Hungary, in Katharina Boele-Woelki (ed), Common Core and Better Law in European Family Law (Intersentia, 2005), pp 313-330

$20 \$ 6: 515$

$21 \$ \$ 4: 86-4: 95$

(C) Palacký University Olomouc, Czech Republic, 2013. ISSN 1213-8770 (print), ISSN: 2464-6601 (online). 
is the main rule as parents exercise parental responsibilities jointly even if they do not live together in lack of their agreement, the court's or the public guardianship authority's decision. ${ }^{22}$

In case of divorce or the splitting up of the cohabitation parents may agree on joint parental responsibilities. In case of divorce upon mutual consent the agreement on the parental responsibilities is one of the ancillary questions and in this case they do not have to agree on contact but have to agree on child's maintenance and determine the residence of the child. ${ }^{23}$ Even if there is no mutual consent when divorcing or parents were not spouses but their common life breaks up they have a possibility to put their agreement on joint parental responsibilities before the court and claim for its approval and this agreement has to extend to the child's residence as well. Concerning the child's residence neither the Family Act nor the new Civil Code knows definitely the possibility of alternating residence, nevertheless, the Family Law Book leaves this opportunity open. Today the alternating residence is not a well-known and well-spread legal institution in Hungary.

The new Civil Code gives some instructions to the parents living apart from each other but exercising joint parental responsibilities. They should provide a balanced lifestyle for their child and both of them have the right to act alone in the interest of the child and besides of informing the other parents if an important decision have to be taken promptly. ${ }^{24}$ In case of a disagreement on an important matter the parents will have the possibility to apply to the guardianship authority. So far the court has had this competence but the new rules delegate some competences to the guardianship authorities. If parents cannot cooperate during the exercising the joint parental responsibilities either of them may claim that the court should terminate the joint parental responsibilities.

\section{The sole exercise of parental responsibilities and the division of the parental rights and obligations}

In case of either divorce upon the spouses' mutual consent or reaching an agreement after the break-up of the relationship the parents who live apart from each other may agree that either of them should exercise the parental responsibilities solely or, as a new possibility, divide the parental rights and obligations. ${ }^{25}$ If they cannot agree the court will decide on the parental responsibilities either upon their claim or ex officio if this is necessary in the child's interest.

Lacking of agreement either party may claim for the court's decision. The court cannot order the joint parental responsibilities against the will of either of the parents so one of the parents may be given the parental responsibilities and

\footnotetext{
$22 \$ 4: 164(1)$

$23 \S 4: 21(3)-(4)$

$24 \$ 4: 164(2)-(3)$

$25 \S 4: 165(1)$
}

(C) Palacký University Olomouc, Czech Republic, 2013. ISSN 1213-8770 (print), ISSN: 2464-6601 (online). 
it is up to the court's discretionary power which parent gets those. According to the judicial practice each circumstance has to be weighed and the crucial is how the child's physical, mental and moral development might be promoted better. In that case the child will reside with the custodial parent and the non-residential parent will have the right to contact with the child. The parent who does not exercise parental responsibilities maintains the right to decide on important matters affecting the child in conjunction with the holder of the parental responsibilities as main rule.

The new Civil Code provides discretional power to the court to empower the non-residential parent to exercise some rights and tasks even besides giving the parental responsibilities to the another parent and, on the other side, even the right to decide on important matters affecting the child in conjunction with the holder of the parental responsibilities might be taken away from the nonresidential parent. This flexibility on the field of the parents' agreements and the judicial decisions seem to serve the child's interest even better.

\section{The rights and obligations of the non-residential parent}

As the number of parents and children who live in separate households after the break-up of the parents' marriage or cohabitation has been growing almost continuously a brand new chapter of the Family Law Book is devoted to the rights and obligations of the non-residential parent. The parent exercising the parental responsibilities and the non-residential parent have to cooperate with each other to be able to provide the balanced lifestyle of the child. Besides, they have to respect each other's family life. ${ }^{26}$ Although no direct sanction is introduced in breaching these obligations it may have - sometimes indirect - consequences on long term.

The parent who does not exercise parental responsibilities maintains the right to decide important matters affecting the child together with the holder of the parental responsibilities. ${ }^{27}$ Both parents are involved in those decisions even lacking joint parental responsibilities. These issues are the determination and change of the minor's name, the child's residence, change of child's citizenship, his or her education and career. In case of the parents' failure in reaching a decision on either of the important matters the public guardianship authority has a competence to decide.

Special obligations are introduced on informing the other party. The residential parent is obliged to inform the other parent about the child's development, health and studies regularly. ${ }^{28}$ If the non-residential parent asks for information the residential parent has to give the information requested for. If the non-residential parent is empowered with some rights and tasks concerning the child

$26 \$ 4: 173$

$27 \$ 4: 175$

$28 \S 4: 174, \S 4: 176$

(C) Palacký University Olomouc, Czech Republic, 2013.

ISSN 1213-8770 (print), ISSN: 2464-6601 (online). 
this parent also has to comply with the requirement of informing the other parent. These obligations are not balanced with any direct sanction. Nevertheless, on longer term there may be indirect consequences.

\section{Parent-child contact}

Nowadays, a lot of parents and children are affected by the issue of contact that is why the Family Law Book regulates this field with detailed rules. According to the main rule and being in harmony with the Convention on Rights of the Child of 1989 the child has a right to keep personal and direct contact with his or her parent. The non-residential parent has a right to maintain contact with his or her child and it is also an obligation on him or her. The custodial parent or person is obliged to provide the undisturbed contact. Although the contact rights of the parent may be restricted in cases defined in the Family Law Book, the right to keep contact with the child is in principal rather strengthened. The factual familial relationships are taken into attention in harmony with the judiciary of the European Court of Human Rights.

New rules are codified concerning the parents' obligation on informing each other without any delay if the actual occasion of parent-child contact is hindered. If the occasion of contact falls off and it is not to be imputed to the nonresidential parent it has to be replaced at the soonest possible and proper date. The emphasis on contact is shown by the introduction of rules on responsibility. ${ }^{29}$ Whenever either parent obstructs the contact without due reason or breaches the regulations on contact is obliged to reimburse the other party's losses. Both the court and the public guardianship authority have competence in contact issues and they may also restrict or revoke this right in the child's interest.

\section{Summary}

At the end of 2013 the Hungarian lawyers are preparing for the application of the new Civil Code including the new family law regulations. We shall see later on how the regulations are shaped in the judiciary and whether the slogan "cautious progress" ${ }^{\prime 30}$ which characterized the Draft of the Family Law Book becomes true.

$29 \$ 4: 183(1)$

30 Cautious progress was the title of the series which published the planned new family law regulations in the periodical Family Law in 2005-2007, the author of the series is András Körös. See also András Körös, New Features of Hungarian Matrimonial Property Law in the Draft of a New Civil Code, in Bea Verschraegen (ed), Family Finances (Jan Sramek Verlag, 2009) pp 675-681. 